\title{
Penerapan Kualitas dan Kemasan Pada Usaha Kerupuk di Desa Lumpatan Sekayu
}

\author{
Omar Hendro, Wani Fitriah \& Belliwati Kosim \\ Universitas Muhammadiyah Palembang \\ Email: omarhendro@ymail.com
}

\begin{abstract}
The application of quality and packaging to the cracker business in Lumpatan Sekayu Village is the title or topic of the Community Service Team. Providing counseling in the field of marketing management that specializes in quality and packaging of crackers. The implementation of this community service is by means of direct counseling to the cracker business owner and their workers. The goal is that crackermaking businesses can increase their production as a result of increased sales. The quality and packaging of the crackers has not been the concern of this cracker business maker. Several findings by the Community Service Team concluded in the report, 1). so far they have not considered the quality and packaging of the crackers. 2). The use of traditional means of production and drying, cracker size is not standard. 3). Do not have a business, health and halal permit from the relevant government agency. 4). The local government still lacks attention to cracker entrepreneurs, which are a household industry involving the workforce of local housewives. The Community Service Team after providing counseling will monitor and guide, so that these cracker processors carry it out. The team will provide a way out or a solution if they find a problem. The ultimate goal of community service is to improve the welfare of the owner and maker of crackers as well as the community in Lumpatan Sekayu Village.
\end{abstract}

Keyword: Quality, packaging, sales and government attention.

\section{Pendahuluan}

\subsection{Latar Belakang}

Kemajuan dan perubahan yang terjadi baik dalam bidang sosial, budaya, politik dan ekonomi, berpengaruh terhadap pola perilaku manusia. Manusia berlomba-lomba memikirkan cara untuk membantu mereka dalam mencapai segala tujuan dan kebutuhannya. Hal tersebut berakibat persaingan semakin ketat, terutama dalam dunia bisnis (Akbar, 2018). Persaingan yang ketat ini memerlukan strategi pemasaran, terutama kualitas dan kemasan produk yang tepat pula agar dapat bersaing.

Untuk memenuhi kebutuhan tersebut manusia melakukan berbagai aktivitas usaha. Berjalannya suatu usaha tidak lepas dari pentingnya sebuah strategi untuk dapat mempertahankan suatu keunggulan kompetitifnya dengan cara mengembangkan produknya serta meningkatkan kualitas yang diberikan kepada setiap konsumen. Untukitu home industri hendaknya memberikan jaminan kualitas produksinya merupakan aspek yang harus dipenuhi oleh setiap perusahaan khususnya pada home industri. Hal ini dilakukan untuk memberikan kepuasan kepada setiap konsumen. Meningkatkan kualitas produk untuk memuaskan konsumen merupakan salah satu hal yang menjadi tujuan bagi setiap perusahaan terlebih produk-produk home industri. Banyak produk yang dihasilkan dengan berbagai macam jenis, mutu, serta bentuk, dimana keseluruhan tersebut ditujukan untuk menarik minat konsumen, sehingga konsumen cenderung akan melakukan aktivitas membeli produk tersebut. Oleh karena 
itu setiap home industri dituntut agar mampu menciptakan produk dengan spesifikasi yang terbaik agar kepuasan konsumen dapat terpenuhi secara optimal. Hal tersebut menuntut home industri untuk dapat merumuskan kembali strategi yang ditempuh untuk meningkatkan kemampuan bersaing dalam melayani konsumen. Usaha menciptakan dan mempertahankan pelanggan hendaknya menjadi prioritas utama bagi perusahaan.

Strategi yang tepat dapat menarik pelanggan hendaknya disusun secara cermat, agar pelanggan mau membeli produk yang dihasilkan perusahaan. Lebih dari itu dengan segala kiatnya perusahaan juga harus berupaya agar pelanggan dapat menjadi setia terhadap produk tersebut. Kualitas memberikan suatu dorongan kepada pelanggan untuk menjalin ikatan hubungan yang kuat dengan home industri. Dalam jangka panjang,ikatan ini memungkinkan perusahaan untuk memahami dengan seksama terhadap harapan pelanggan serta kebutuhannya. Dengan demikian home industry dapat meningkatkan kepuasan pelanggan dimana home industry memaksimumkan pengalaman para pelanggan yang menyenangkan dan meminimumkan pengalaman pelanggan yang kurang menyenangkan.

Produk merupakan salah satu dari faktor yang dapat mempengaruhi keunggulan bersaing, di samping harga dan jangkauan distribusinya. Oleh karena itu setiap home industri mengembangkan produknya, agar mampu bersaing dengan produk-produk perusahaan di pasar. Unsur yang terpenting dalam produk adalah mutu atau kualitas.

Sering terdapat perbedaan penafsiran tentang apa yang dimaksud dengan kualitas. Dari segi pandangan produsen, mutu atau kualitas sering diartikan sebagai komposisi teknis yang didasarkan pada spesifikasi teknis dari suatu produk. Sedangkan dari segi pandangan konsumen, kualitas dimaksudkan sebagai tingkat kemampuan produk untuk memenuhi apa yang diharapkan konsumen terhadap produk yang dimilikinya. Apa yang diharapkan si konsumen dapat berupa daya tahan atau umur dari suatu produk serta kualitas produk itu sendiri dengan harga yang lebih terjangkau namun tetap berkualitas. Oleh karena itu dari sisi pandangan kosumen, kualitas produk sangat terkait dengan kepuasan konsumen. Dengan terdapatnya kepuasan dari suatu produk oleh konsumen, maka makin baiklah posisi produk itu dalam persaingan, karena makin banyak dicari dan diminta produk tersebut oleh para konsumen.Peningkatan produktivitas pada home industri dapat dilakukan dengan memaksimalkan pemanfaatan waktu yang tersedia untuk menghasilkan output yang lebih besar atau mengurangi penggunaan waktu kerja untuk menghasilkan output yang tepat. Kompetensi tenaga kerja, metode dan peralatan kerja yang sesuai dengan pekerjaan mampu meningkatkan waktu kerja yang efisien, sehingga dapat menghasilkan produk yang maksimal. Serta dapat meminimalkan kesalahan untuk meningkatkan hasil produksi.

Hal yang tidak kalah pentingnya yaitu pengemasan produk. Peningkatkan volume penjualan, pengrajin atau pengusaha harus memberikan keunikan atau ciri khas dari produk. Salah satunya yaitu kemasan produk yang mempunyai peranan penting dalam penjualan. Di mana kemasan saat ini bukan hanya sebagai pembungkus, tetapi juga bisa dijadikan sebagai salah satu alat promosi efektif yang dapat memberikan informasi kepada konsumen mengenai produk tersebut. Oleh karena itu dalam membuat kemasan harus dibuat sebagus mungkin. Menurut Alma $(2002 ; 116)$ fungsi kemasan adalah sebagai berikut: melindungibarang-barang yang dibungkusnya sewaktu barang-barang tersebut bergerak melalui proses-proses marketing dan memudahkan pedagang- 
pedagang eceran dalam membagi-bagi atau memisahkan barang tersebut. Melalui pengemasan produk, diharapkan dapat meningkatkan nilai daya tarik dari sebuah produk, sekaligus untuk mengidentifikasi mudah dikenalnya suatu produk karena adanya label atau merek yang tertera dalam pembungkus. Pembungkus juga dapat digunakan sebagai alat komunikasi karena membawa berita atau catatan mengenai produk tersebut.

Proses Produksi Kerupuk

Pengolahan kerupuk ikan hanya dari pengolahan bahan mentah sampai pada proses kerupuk siap goreng. Adapun proses pengolahannya adalah sebagai berikut:

1) Proses penyiapan bahan baku

Proses penyiapan bahan baku adalah persiapan daging ikan, tepung serta bumbu-bumbu sesuai dengan perhitungan komposisi masing-masing bahan untuk setiap adonan. Dalam proses ini Bahan baku ikan perlu mendapat perhatian utama. Mutu ikan yang digunakan akan mempengaruhi mutu produksi kerupuk ikan, oleh karena itu perlu dipilih ikan yang masih segar. bengan demikian diperlukan pengetahuan untuk mengetahui tandatanda ikan dengan mutu yang baik (masih segar). Ketiadaan ikan segar yang musiman ini akan digantikan rempah teri yang di dapatkan di pasar sekayu. Ketersediaan bahan baku ini selalu ada dan tidak tergantung musim. Inilah alternatif jika ikan kecil sungai tidak tersedia.

Sebelum dihaluskan, ikan dibersihkan dahulu dengan cara menghilangkan sisik, insang, maupun isi perutnya kemudian dieuci sampai bersih. Bagian tubuh yang keras, seperti duri maupun tulang dibuang karena dapat menurunkan mutu kerupuk yang dihasilkan. Selanjutnya ikan tersebut digiling sampai halus. Di samping itu bahan baku berupa tepung dan telur serta bumbu disiapkan untuk proses adonan.

Komposisi Bumbu, mulanya sediakan bumbu dengan jumlah sebagai berikut : bawang putih, ikan (sesuai selera), dan garam untuk $1 \mathrm{~kg}$ (20 gr) tepung sagu. Bawang putih digiling harus bersama garam, ikan dijemur atau dikeringkan sampai benar-benar kering (kadar air (6\%). Ikan dapat juga disangrai sampai kering. Ikan yang telah kering tersebut digiling sampai halus berupa tepung ikan. Tepung ikan dicampur dengan bawang putih. Aduk sampai rata, campuran adalah bumbu kerupuk.

2) Pengukusan kerupuk

Adonan yang sudah dicetak berbentuk keriting/kerupuk dikukus selama 1-2 jam sampai bagian dalamnya matang. Hasil yang diperoleh disebut dengan dodolan matang.

3) Proses pembentukan adonan

Adonan dibuat dari tepung tapioka yang dicampur dengan bumbu-bumbu yang digunakan. Tepung diberi air dingin hingga menjadi adonan yang kenta!. Bumbu dan ikan yang telah digiling halus dimasukkan ke dalam adonan dan diaduk/diremas hingga lumat dan rata. Adonan ini kemudian dimasukkan ke dalam mulen untuk pelembutan, dan akan diperoleh adonan yang kenyal dengan campuran bahan merata.

Pembuatan biang kerupuk ; pencampuran dengan bumbu kerupuk, tepung sagu dibagi dua, yaitu $1 / 3$ bagian dan $2 / 3$ bagian. Bagian 1/3 dicampur dengan air dan bumbu kerupuk. Setiap $1 \mathrm{~kg}$ tepung sagu dicampur dengan 1,7 liter air. Campuran tersebut 
diaduk sampai rata. Pemasakan ; campuran di atas dimasak sambil diaduk sampai menjadi lem kental. Hasil pemasakan ini disebut dengan biang kerupuk.

Pembuatan Adonan; pembuatan adonan. Campur biang kerupuk sedikit-sedikit dengan tepung sagu $2 / 3$ bagian, lalu aduk hingga rata sambil diulen sampai jadi adonan yang tidak lengket ditangan. Pembentukan adonan, dibentuk silinder atau seperti dodol.

4) Pencetakan

Pencetakan adonan dapat dilakukan dengan tangan, berukuran sekitar $5 \mathrm{~cm}$ sampai dengan $6 \mathrm{~cm}$. Kemudian adonan berbentuk kriting/kerupuk dikukus dalam kukusan yang terbuat dari aluminium.

5) Pengukusan

Adonan sudah berbentuk cetakan kerupuk kemudian dikukus dalam dandang selama kurang lebih 2 jam sampai masak. Untuk mengetahui apakah adonan kerupuk telah masak atau belum adalah dengan cara menusukkan lidi ke dalamnya. Bila adonan tioak melekat pada lidi berarti adonan telah masak. Cara lain untuk menentukan masak atau tidaknya adonan kerupuk dapat dilakukan dengan menekan adonan tersebut. Bila permukaan kerupuk kembali seperti semula, artinya adonan telah masak.

6) Pendinginan

Kerupuk yang telah masak segera diangkat dan didinginkan. Kerupuk yang telah dikukus tadi kemudian didinginkan di udara terbuka kurang lebih 1 (satu) hari atau kurang lebih 24 jam hingga kerupuk menjadi keras dan mudah untuk dijemur.

7) Pengeringan/penjemuran

Kerupuk mentah kemudian dijemur sampai kering. Penjemuran dilakukan di bawah sinar matahari kurang lebih 4 jam. Pada saat musim hujan untuk pengeringan kerupuk yang masih basah dapat dilakukan di dalam rumah. Pengusaha kerupuk belum mempunyai oven (dryer), sehingga pasa saat musim hujan, menjadi kendala saat pengeringan. Tetapi kerupuk yang dikeringkan dengan sinar matahari hasilnya akan lebih bagus dibandingkan jika penjemuran di dalam rumah. Kerupuk yang dikeringkan dengan sinar matahari jika digoreng akan lebih mengembang. Hal ini akan lebih menguntungkan para pengusaha penggorengan kerupuk dan akan mempengaruhi harga kerupuk. Karena itulah pengeringan menggunakan sinar matahari lebih disukai. Anginkan kerupuk basah selama kurang lebih 12 jam, lalu keringkan sampai kadar air berkurang 9-10 liter.

\section{8) Pengepakan/pembungkusan}

Setelah kering, kerupuk segera diangkat dari jemuran. Kerupuk yang telah kering dapat segera dibungkus dan dijual. Biasanya kerupuk ikan siap goreng dikemas dalam plastik sejumlah jumlah tertentu. Kemasan kerupuk dalam plastik $1 \mathrm{~kg}$ sampai dengan 1,5 kg. sedangkan pembungkusan kerupuk yang sudah digoreng di kemas dalam kantong plastik sejumlah 15 - 20 kerupuk goring.

Harga perkilogram kerupuk mentah berkisar Rp 25.000,- Rp. 30.000,-. Sedangkan yang sudah digoreng sejumlah 15 kerupuk harganya sekitar Rp. 10.000,-

9) Penggorengan 
Kerupuk mentah jadi, dan siap digoreng di minyak panas selama 20 detik. Ingat, hatihati dalam proses penggorengan, jangan sampai kerupuk gosong. Aturlah suhu panas kompor, usahakan api jangan terlalu menyala besar dan jangan terlalu kecil juga, agar kerupuk matang sempurna.

\subsection{Permasalahan Objek di Pengabdian Kepada Masyarakat}

Tim pengabdian masyarakat mengamati adanya permasalahan dalam peningkatan penjualan usaha kerupuk ini. Kualitas dan pengemasan belum diperhatikan para usahawan kerupuk di Desa Lumpatan Sekayu ini. Kualitas kerupuk yang mereka jual belum mempunyai standar dari citarasa, perbandingan bahan baku dalam proses produksi. Hal ini terjadi karena kurangnya pengetahuan mereka dalam menjaga kualitas dan pengemasan kerupuk yang mereka produksi. Proses produksi pembuatan kerupuk ini mereka lakukan berdasarkan pengalaman tanpa mempunyai ukuran yang jelas. Begitupun dengan kemasan, tanpa lebel tentang produk tersebut.

\subsection{Manfaat Yang Diharapkan}

Tim pengabdian masyarakat ini mengharapkan dengan adanya penyuluhan tentang kualitas dan kemasan produk, dapat meningkatkan produksi akibat dari meningkatnya penjualan. Para usaha pembuat kerupuk ini menjaga kualitas kerupuk mulai dari kualitas bahan baku yang mereka gunakan, proses produksi dengan menggunakan peralatan yang baik (tidak rusak) dan bersih serta pengolahan menggunakan ukuran dengan perbandingan yang tepat. Sehingga kerupuk yang mereka hasilkan berkualitas.

Pengemasan kerupuk baik yang masih mentah (siap goring) maupun yang sudah digoreng menarik minat pembeli. Kemasan memiliki informasi tentang produk, cara penggorengan (kerupuk mentah), alamat produsen, serta masa kadaluarsa kerupuk tersebut.

\section{Tinjauan Literatur}

\subsection{Kualitas Produk}

\subsubsection{Pengertian Kualitas Produk}

Produk memiliki arti penting bagi perusahaan karena tanpa adanya produk, perusahaan tidak akan dapat melakukan apapun dari usahanya. Pembeli akan merasa cocok, karena itu produk harus disesuaikan dengan keinginan ataupun kebutuhan pembeli agar pemasran produk dapat berhasil. Dengan kata lain, pembuatan produk lebih baik diorientasikan pada keinginan pasar atau selera konsumen. Menurut Assauri (2016:85) produk merupakan hasil dari kegiatan produksi, yang meliputi sekumpulan atribut fisik nyata yang terakit dalam sebuah bentuk yang dapat diidentifikasikan. Menurut Kotler (2015) bahwa kualitas merupakan suatu kondisi dinamis yang berhubungan dengan produk, jasa, manusia, proses, dan lingkungan yang memenuhi atau melebihi harapan.3Sedangkan kualitas adalah sejauh mana produk memenuhi spesifikasi-spesifikasinya. Sedangkan menurut Kotler dan Amstrong kualitas produk merupakan salah satu sarana positioning utama pasar. Kualitas produk mempunyai dampak langsung pada kinerja produk atau jasa, oleh karena itu kualitas berhubungan erat dengan nilai pelanggan.

\subsubsection{Alasaan Memproduksi Produk Berkualitas}


Produk berkualitass prima memang akan lebih atraktif bagi konsumen bahkan akhirnya dapat meningkatkan volume penjualan. Tetapi leih dari itu produk berkualitas mempunyai aspek penting lain, yaitu :

1) Konsumen yang membeli produk berdasarkan mutu.

Umumnya konsumen mempunyai loyalitas produk yang besar dibandingkan dengan konsumen yang membeli berdasarkan orientasi harga. Konsumen berbasis mutu akan selalu membeli produk tersebut sampai saat produk tersebut membuat dia merasa tidak puas karena adanya produk lain yang lebih bermutu. Tetapi selama produk semula masih selalu melakukan perbaikan mutu (quality improvement) dia akan tetap setia dengan tetap membelinya. Berbeda dengan konsumen berbasis harga, dia akan mencari produk yang harganya lebih murah, apapun mereknya. Jadi konsumen terakhir tersebut tidak mempunyai loyalitas produk.

2) Bersifat kontradiktif dengan cara pikir bisnis tradisional.

Ternyata bahwa memproduksi barang bermutu, tidak secara otomatis lebih mahal dengan memproduksi produk bermutu rendah. Banyak perusahaan menemukan bahwa memproduksi produk bermutu tidak harus berharga lebih mahal. Menghasilkan produk bermutu tinggi secara simultan meningkatkan produktivitas, antara lain mengurangi penggunaan bahan (reduce materials usage) dan mengurangi biaya.

3) Menjual barang tidak bermutu.

Kemungkinan akan banyak menerima keluhan dan pengembalian barang dari konsumen. Atau biaya untuk memperbaikinya menjadi sangat besar, selain memperoleh citra tidak baik. Belum lagi, kecelakaan yang diderita konsumen akibat pemakaian produk yang bermutu rendah. Konsumen tersebut mungkin akan menuntut ganti rugi melalui pengadilan. Jadi, berdasarkan ketiga alasan tersebut, memproduksi produk bermutu tinggi lebih banyak akan memberikan keuntungan bagi produsen, bila dibandingkan dengan produsen yang menghasilkan produk bermutu rendah.

\subsubsection{Dimensi Kualitas Produk}

Sifat khas mutu suatu produk yang handal harus mempunyai dimensi, karena harus member kepuasan dan nilai manfaat yang besar bagi konsumen dengan melalui berbagai cara. Menurut Tjiptono (2016:118) kualitas memiliki delapan dimensi pengukuran yang terdiri atas aspek-aspek sebagai berikut:

1) Perfomance, kinerja di sini merujuk pada karakter produk inti yang meliputi merek, atribut-atribut yang dapat diukur, dan aspek-aspek kinerja individu. Kinerja produk biasanya didasari oleh preferensi subjektif pelanggan yang pada dasarnya bersifat umum.

2) Featurs yaitu aspekyang berguna untuk menambah fungsi dasar, berkaitan dengan pilihan-pilihan produk dan pengembangannya.

3) Reliability, halyang berkaitan dengan probabilitas atau kemungkinan suatu barang berhasil menjalankan fungsinya setiap kali digunakan.

4) Canformance, hal ini berkaitan dengan tingkat kesesuaian terhadap spesifikasi yang telah ditetapkan sebelumnya berdasarkan keinginan pelanggan 
5) Durability, yaitu suatu refleksi umur ekonomis berupa ukuran daya tahan atau masa pakai barang.

6) Servieability. yaitu karakteristik yang berkaitan dengan kecepatan, kompetensi, kemudahan, dan akurasi dalam memberikan layanan untuk perbaikan barang.

7) Asthetics, merupakan karakterisitik yang bersifat subyektif mengenai nilai estetika yang berkaitan dengan pertimbangan pribadi dan refleksi dari preferensi individual.

8) Percived quality, konsumen tidak selalu memiliki informasi lengkap mengenai atribut-atribut produk. Namun demikian, biasanya konsumen memiliki informasi tentang produk secara tidak langsung.

Kualitas merupakan faktor yang terdapat dalam suatu produk yang menyebabkan suatu produk tersebut bernilai sesuai dengan maksud untuk apa produk di produksi. Kualitas ditentukan oleh sekumpulan kegunaan atau fungsinya, termasuk di dalamnya daya tahan, ketergantungan pada produkatau komponen lain (kenyamanan dan wujud luar seperti warna, bentuk, pembungkus dan sebainya).

Indikator Kualitas Produk 1). Kadar produk.2). Desain produk.3). Daya tahan produk.

\subsection{Kemasan Produk}

\subsubsection{Pengertian Kemasan}

Kemasan adalah desain kreatif yang mengaitkan bentuk, struktur, material, warna, citra, tipografi dan elemen-elemen desain dengan informasi produk agar produk dapat dipasarkan. Kemasan digunakan untuk membungkus, melindungi, mengirim, mengeluarkan, menyimpan, mengidentifikasi dan membedakan sebuah produk di pasar (Klimchuk dan Krasovec, 2006:33).

Menurut Kotler \& Keller (2009:27), pengemasan adalah kegiatan merancang dan memproduksi wadah atau bungkus sebagai sebuah produk. Pengemasan adalah aktivitas merancang dan memproduksi kemasan atau pembungkus untuk produk. Biasanya fungsi utama dari kemasan adalah untuk menjaga produk. Namun, sekarang kemasan menjadi faktor yang cukup penting sebagai alat pemasaran (Rangkuti, 2010:132).

Kemasan yang dirancang dengan baik dapat membangun ekuitas merek dan mendorong penjualan. Kemasan adalah bagian pertama produk yang dihadapi pembeli dan mampu menarik atau menyingkirkan pembeli. Pengemasan suatu produk biasanya dilakukan oleh produsen untuk dapat merebut minat konsumen terhadap pembelian barang. Produsen berusaha memberikan kesan yang baik pada kemasan produknya dan menciptakan model kemasan baru yang berbeda dengan produsen lain yang memproduksi produk-produk sejenis dalam pasar yang sama.

\subsubsection{Fungsi Kemasan}

Perusahaan sangat memperhatikan pembungkus suatu barang sebab mereka menganggap bahwa fungsi kemasan tidak hanya sebagai pembungkus, tetapi jauh lebih luas dari pada itu. Simamora (2007) mengemukakan pengemasan mempunyai dua fungsi yaitu:

\section{1) Fungsi Protektif}

Berkenaan dengan proteksi produk, perbedaan iklim, prasarana transportasi, dan saluran 
distribusi yang semua berimbas pada pengemasan. Dengan pengemasan protektif, para konsumen tidak perlu harus menanggung risiko pembelian produk rusak atau cacat.

2) Fungsi Promosional

Peran kemasan pada umumnya dibatasi pada perlindungan produk. Namun kemasan juga digunakan sebagai sarana promosional. Menyangkut promosi, perusahaan mempertimbangkan preferensi konsumen menyangkut warna, ukuran, dan penampilan.

Sedangkan menurut Kotler (1999:228), terdapat empat fungsi kemasan sebagai satu alat pemasaran, yaitu :

1) Self service.

Kemasan semakin berfungsi lebih banyak lagi dalam proses penjualan, dimana kemasan harus menarik, menyebutkan ciri-ciri produk, meyakinkan konsumen dan memberi kesan menyeluruh yang mendukung produk.

2) Consumer of fluence.

Konsumen bersedia membayar lebih mahal bagi kemudahan, penampilan, ketergantungan dan prestise dari kemasan yang lebih baik.

3) Company and brand image.

Perusahaan mengenal baik kekuatan yang dikandung dari kemasan yang dirancang dengan cermat dalam mempercepat konsumen mengenali perusahaan atau merek produk.

\section{4) Inovational opportunity.}

Cara kemasan yang inovatif akan bermanfaat bagi konsumen dan juga memberi keuntungan bagi produsen.

Selain berfungsi sebagai media pemasaran, kemasan juga memiliki beberapa fungsi lain, yaitu 1). Kemasan melindungi produk dalam pergerakan. Salah satu fungsi dasar kemasan adalah untuk mengurangi terjadinya kehancuran, busuk, atau kehilangan melalui pencurian atau kesalahan penempatan. 2). Kemasan memberikan cara yang menarik untuk menarik perhatian kepada sebuah produk dan memperkuat citra produk. 3). Kombinasi dari keduanya, marketing dan Logistik dimana kemasan menjual produk dengan menarik perhatian dan mengkomunikasikannya.

\subsubsection{Tujuan Kemasan}

Menurut Louw dan Kimber (2007), kemasan dan pelabelan kemasan mempunyai beberapa tujuan, yaitu:

1) Physical Production.

Melindungi objek dari suhu, getaran, guncangan, tekanan dan sebagainya.

Barrier Protection. Melindungi dari hambatan oksigen uap air, debu, dan sebagainya.

2) Containment or Agglomeration.

Benda-benda kecil biasanya dikelompokkan bersama dalam satu paket untuk efisiensi transportasi dan penanganan. 


\section{3) Information Transmission.}

Informasi tentang cara menggunakan transportasi, daur ulang, atau membuang paket produk yang sering terdapat pada kemasan atau label.

4) Reducing Theft.

Kemasan yang tidak dapat ditutup kembali atau akan rusak secara fisik (menunjukkan tanda-tanda pembukaan) sangat membantu dalam pencegahan pencurian. Paket juga termasuk memberikan kesempatan sebagai perangkat anti-pencurian.

5) Convenience.

Fitur yang menambah kenyamanan dalam distribusi, penanganan, penjualan, tampilan, pembukaan, kembali penutup, penggunaan dan digunakan kembali.

6) Marketing.

Kemasan dan label dapat digunakan oleh pemasar untuk mendorong calon pembeli untuk membeli produk.

\subsubsection{Jenis-jenis Kemasan}

Berdasarkan struktur isi, kemasan dibagi menjadi tiga jenis, yaitu:

1) Kemasan Primer, yaitu bahan kemas langsung mewadahi bahan pangan (kaleng susu, botol minuman, dll).

2) Kemasan Sekunder, yaitu kemasan yang fungsi utamanya melindungi kelompok kemasan lainnya, seperti misalnya kotak karton untuk wadah kaleng susu, kotak kayu untuk wadah buah-buahan yang dibungkus dan sebagainya.

3) Kemasan Tersier dan Kuarter, yaitu kemasan yang diperlukan untuk menyimpan, pengiriman atau identifikasi. Kemasan tersier umumnya digunakan sebagai pelindung selama pengangkutan.

Berdasarkan frekuensi pemakaiannya, kemasan dibagi menjadi tiga jenis, yaitu:

1) Kemasan sekali pakai (Disposable), yaitu kemasan yang langsung dibuang setelah satu kali pakai. Contohnya bungkus plastik, bungkus permen, bungkus daun, karton dus, makanan kaleng.

2) Kemasan yang dapat dipakai berulang kali (Multi Trip), kemasan jenis ini umumnya tidak dibuang oleh konsumen, akan tetapi dikembalikan lagi pada agen penjual untuk kemudian dimanfaatkan ulang oleh pabrik. Contohnya botol minuman dan botol kecap.

3) Kemasan yang tidak dibuang (Semi Disposable). Kemasan ini biasanya digunakan untuk kepentingan lain di rumah konsumen setelah dipakai. Contohnya kaleng biskuit, kaleng susu dan berbagai jenis botol.

Berdasarkan tingkat kesiapan pakai, kemasan dibagi menjadi dua jenis, yaitu:

1) Kemasan siap pakai, yaitu bahan kemas yang siap untuk diisi dengan bentuk yang telah sempurna sejak keluar dari pabrik. Contohnya adalah wadah botol, wadah kaleng, dan sebagainya.

2) Kemasan siap dirakit, yaitu kemasan yang masih memerlukan tahap perakitan sebelum pengisian, misalnya kaleng dalam bentuk lempengan dan silinder fleksibel, wadah yang terbuat dari kertas, foil atau plastik. 
Teori-teori tentang kualitas dan kemasan produk ini akan disampaikan penyuluh kepada para pembuat kerupuk di Desa Lumpatan Sekayu.

\subsection{Konsep Pemikiran}

Gambar 1. Kerangka Konseptual dan Tujuan Pengabdian Masyarakat

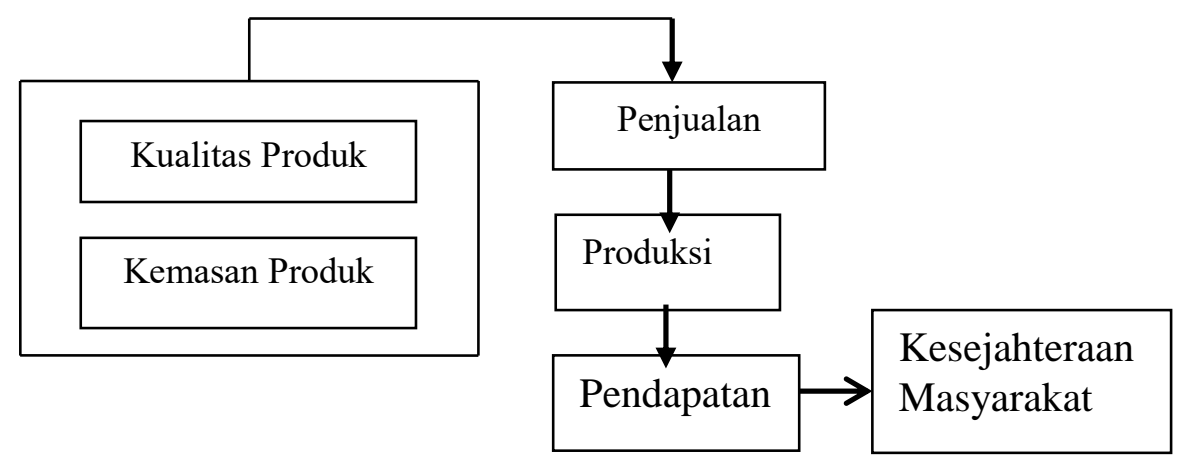

Sumber : Pemikiran Tim berdasarkan Teori, 2020

\section{Metode Pelaksanaan}

Kegiatan pengabdian kepada masyarakat yang pada hakikatnya bertujuan membantu masyarakat agar dapat mampu memenuhi kebutuhannya, harus dilandasi dengan kepercayaan, kemampuan dan kekuatan masyarakat itu sendiri. Untuk membantu pengusaha memenuhi kebutuhan tersebut, kami menawarkan metode untuk membantu mengatasi permasalahan yang dihadapi pengusaha kerupuk di desa Lumpatan Sekayu.

Langkah-langkah Pelaksanaan :

1) Tahap Pencarian Data

Mencari informasi ke kantor desa mengenai potensi produk apa yang unggul yang dimiliki oleh Desa Lumpatan Sekayu, serta mencari data warga masyarakat yang sedang mengembangkan produk unggulan tersebut. Tim dibantu alumni yang berdomisili di Desa Lumpatan ini.

2) Tahap Koordinasi

Tahapan ini meliputi kegiatan melakukan koordinasi dengan warga yang sedang mengembangkan produk unggulan untuk berpartisipasi dalam penyuluhan mengenai bagaimana cara untuk menjaga kualitas dan pengemasan produk. Koordinasi dilakukan dengan melakukan komunikasi dengan alumni yang bertempat tinggal di desa tersebut.

3) Tahap Persiapan

Tahap persiapan dilakukan dengan menyiapkan alat dan bahan yang akan digunakan untuk sosialisasi. Selain itu memastikan bahwa narasumbertelah menyiapkan materi 
yang akan disampaikan.

4) Tahap Penyuluhan

Pada tahap penyuluhan ini terdapat dua tahap pelaksanaan. Tahap pertama adalah pembukaan dengan paparan pengalaman oleh masing-masing penguasaha kerupuk yang geluti selam ini. Tahap kedua yaitu kegiatan penyuluhan tentang kualitas dan pengemasan produk.

5) Tahap Evaluasi

Tahap evaluasi dilakukan setelah dilakukan penyuluhan tentang kualitas dan pengemasan kerupuk. Evaluasi dapat dilihat dari antusias, keaktifan, kreatifitas serta kepahaman para pengusaha kerupuk melaksanakan produksi dan penjualannya.

\section{Pelaksanaan Kegiatan}

\subsection{Anggaran Biaya}

Pelaksanaan program pengabdian kepada masyarakat ini biaya keseluruhan secara mandiri. Pembiayaan ini ditanggung bersama oleh Tim Pengabdian Masyarakat serta beberapa alumni yang bertempat tinggal di Desa Lumpatan Sekayu. Total rincian pembiayaan adalah Rp. 3.260.000 (tiga juta dua ratus enam puluh ribu rupiah) dengan rincian sebagai berikut:

Tabel 1. Anggaran Biaya Tim Pengabdian Masyrakat

\begin{tabular}{|l|l|r|}
\hline No. & \multicolumn{1}{|c|}{ Jenis Pengeluaran } & Biaya (Rp.) \\
\hline 1 & Penyuluh (Tim Pengabdian Masyarakat) & 0 \\
\hline 2 & Bahan habis pakai (ATK peserta) & 435.000 \\
\hline 3 & Konsumsi peserta & 950.000 \\
\hline 4 & Perjalanan dan Konsumsi & 1.125 .000 \\
\hline 5 & Pembelian hasil produksi (kerupuk) & 250.000 \\
\hline 6 & Pembuatan laporan dan publis & 500.000 \\
\hline \multicolumn{2}{|l|}{ Total biaya } & 3.260 .000 \\
\hline
\end{tabular}

\subsection{Jadwal Kegiatan}

Tabel 2. Jadwal Kegiatan Tim Pengabdian Masyrakat

\begin{tabular}{|c|c|c|c|c|c|}
\hline \multirow[t]{2}{*}{ No. } & \multirow{2}{*}{ Kegiatan } & \multicolumn{4}{|c|}{ Minggu Ke- } \\
\hline & & 12 & 3 & 4 & 5 \\
\hline \multirow[t]{2}{*}{1} & Tahap Pencarian Data & & & & \\
\hline & $\begin{array}{l}\text { Ke kantor desa mengenai potensi produk apa yang unggul } \\
\text { yang dimiliki oleh Desa Lumpatan Sekayu }\end{array}$ & & & & \\
\hline
\end{tabular}




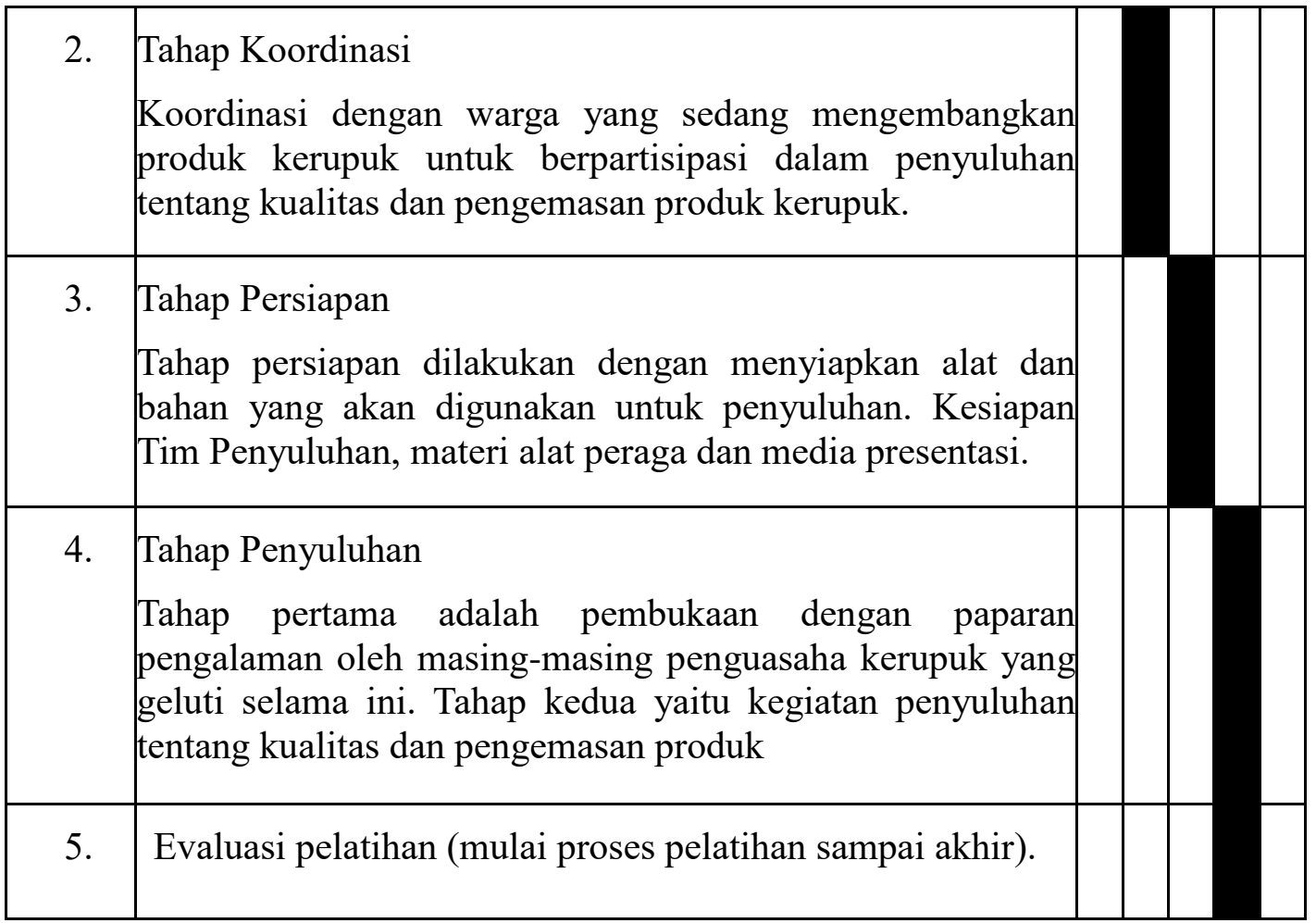

Tim Penyuluhan dan pembimbingan tata cara menjaga kualitas dan pengemasan kerupuk para pengusaha/pembuat kerupuk di desa Lumpatan Sekayu, akhirnya membuat laporan hasil kegiatan. Hasil pengamatan tim dari pelaksanaan penyuluhan dapat di simpulkan pertama, para peserta penyuluhan antusias mengikuti semua materi yang disampaikan Tim Penyuluh. Kedua, para peserta penyuluhan mengerti tujuan menjaga kualitas dan perlunya pengemasan yang baik dan informatif. Ketiga, para peserta penyuluhan memahami manfaat menjaga menjaga kualitas dan perlunya pengemasan yang baik dan informatif. Keempat, para peserta penyuluhan memahami keinginan para pembeli kerupuk. Kelima, para peserta penyuluhan menyadari bahwa selama ini mereka tidak mempertimbangkan kualitas dan kemasan kerupuk yang mereka produksi dan jual. Keenam, penggunaan sarana produksi dan pengeringan yang masih tradisional, ukuran kerupuk tidak sama atau standar serta pengeringan mengandalkan sinar matahari. Hal ini karena tidak punya oven pengering. Ketujuh, usaha kerupuk di Desa Lumpatan Sekayu belum mempunyai ijin usaha dari Dinas Perindustrian dan Perdagangan Kabupaten MUBA. Kedelapan, pengelolaan Usaha kerupuk di Desa Lumpatan Sekayu belum di jamin kesehatannya oleh Balai POM Kabupaten MUBA. Kesembilan, kerupuk hasil usaha masyarakat Desa Lumpatan Sekayu mempunyai sertfikat halal dari MUI Kabupaten MUBA. Kesepuluh, masih minimnya perhatian pemerintah setempat, terhadap pengusaha kerupuk yang merupakan industri rumah tangga yang melibatkan tenaga kerjanya ibu-ibu rumah tangga sekitar.

\section{Kesimpulan}

Dari kegiatan penyuluhan dan pembimbingan tata cara menjaga kualitas dan pengemasan kerupuk para pengusaha/pembuat kerupuk di desa Lumpatan Sekayu ini dapat disimpulkan terlaksana dengan efektif dimana peserta pelatihan yang merupakan industri rumah tangga usaha kerupuk yang tenaga kerjanya ibu-ibu rumah tangga sekitar 
mendapatkan pemahaman mengenai kegiatan proses pengemasan produk dan pemasaran yang sesuai dengan kebutuhan masyarakat yaitu higienis dan menarik kemasannya.

\section{Referensi}

Alma, B. (2002). Manajemen Pemasaran dan Pemasaran Jasa, Bandung: Alfabeta.

Cakera, I. K. (2012). Bangun Wirausaha Idealnya Rp. 5 Miliar per Tiap Tahun, Suara Pembaharuan, Selasa 3 April 2012.

Hasan, S. (2011). Jumlah Wirausaha Indonesia Masih rendah. Kompas.com, Minggu 27 Februari 2011.

Louw, A. \& Kimber, M. (2007). The Power of Packaging, The Customer Equity Company.

Klimchuk, M., \& Krasovec, S. A. (2006). Desain Kemasan. Jakarta: Erlangga.

Kotler \& Keller. (2016). Manajemen Pemasaran. Jilid I. Edisi ke 13. Jakarta: Erlangga.

Poerwanto. (2006). New Business Administration. Yogyakarta: Pustaka Pelajar.Stanton, W. J. (2001). Prinsip Pemasaran. Erlangga. Jakarta.

Rangkuti, F. 2005. Analisis SWOT: Teknik Membedah Kasus Bisnis. Jakarta: Gramedia.

Assauri, S. (2018). Manajemen Pemasaran. Edisi 16. Jakarta. Rajagrafindo

Kotler, Philip \& Susanto. (2001). Dasar-Dasar Pemasaran. Jilid 2. Jakarta: Salemba Empat.

Simamora, B. (2007). Panduan Riset dan Perilaku Konsumen. Jakarta: Gramedia.

Tjiptono, F. (2016). Strategi Pemasaran. Edisi Ketiga. Penerbit Andi. Yogyakarta

Wijayanti, T. (2012). Marketing Plan! Perlukah?. Jakarta: PT. Elex Media Komputindo.

Lampiran: Foto-Foto Selama Kegiatan

Gambar 1. Kunjungan Tim ke lokasi Pengabdian Masyarakat 

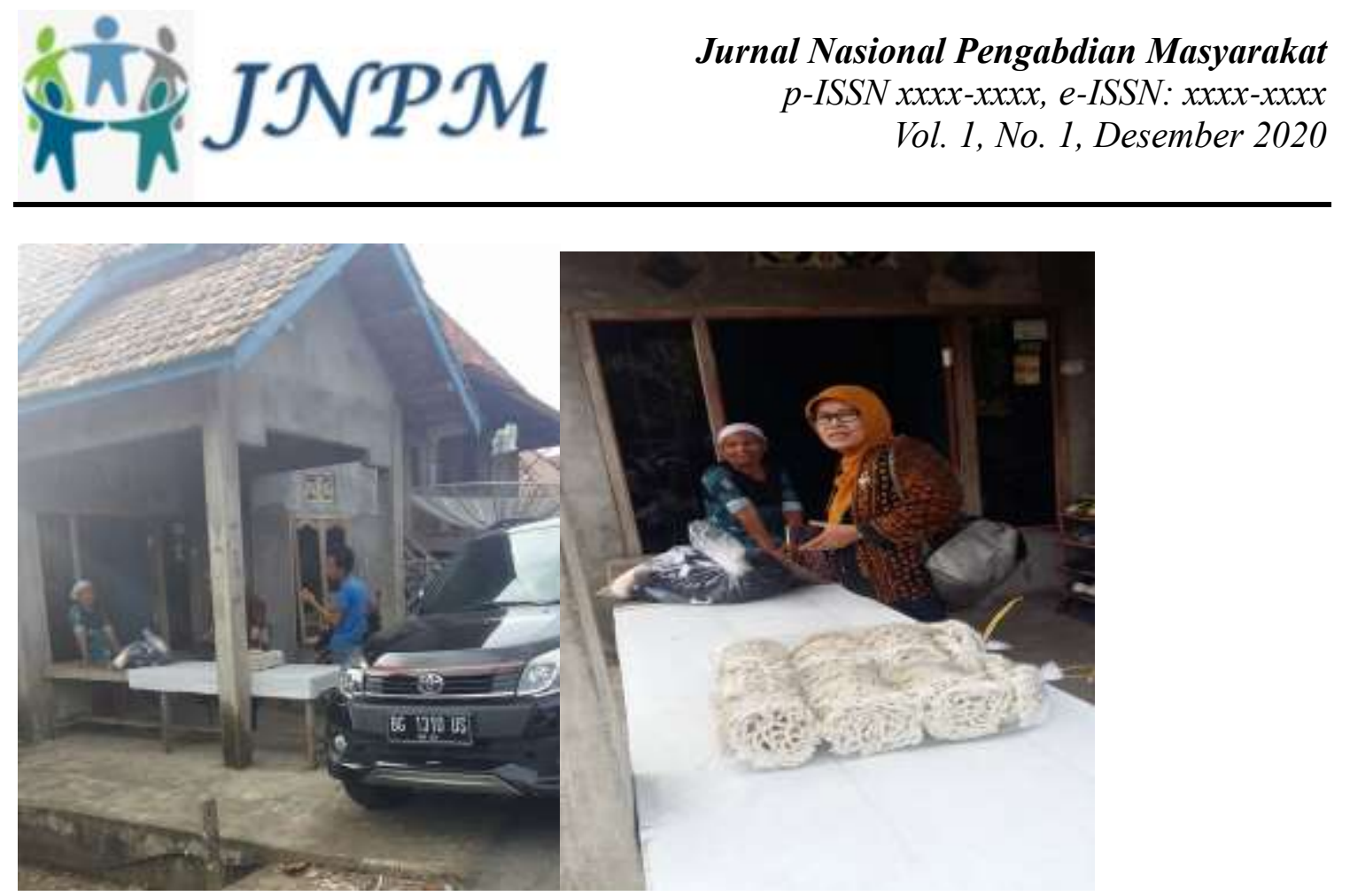

Gambar 2. Proses Pembuatan Kerupuk di Desa Lumpatan Sekayu.

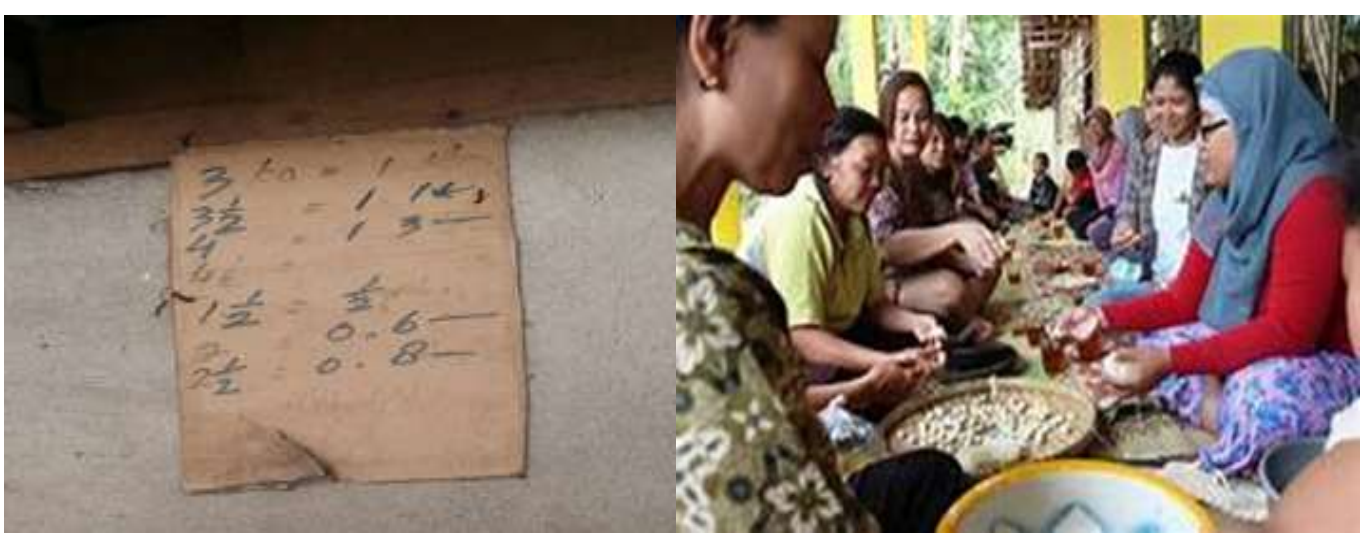

Gambar 3. Proses Pegukusan dan pengeringan Kerupuk

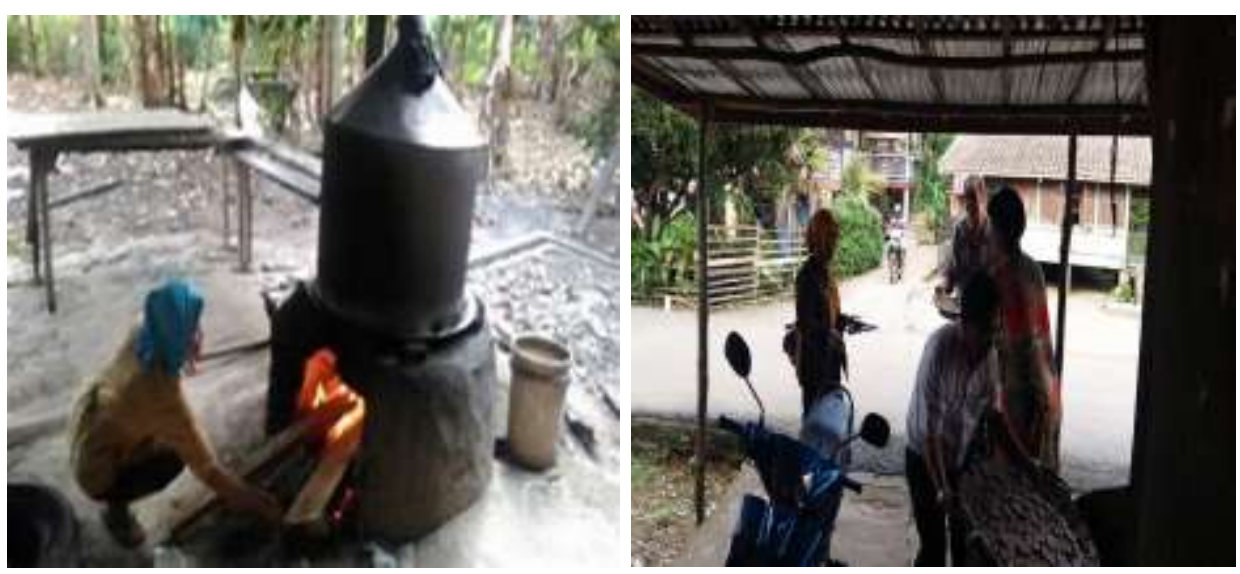

Gambar 4. Proses Penjemuran dan pengemasan Kerupuk

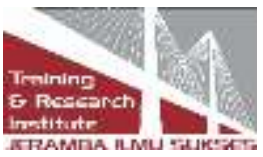



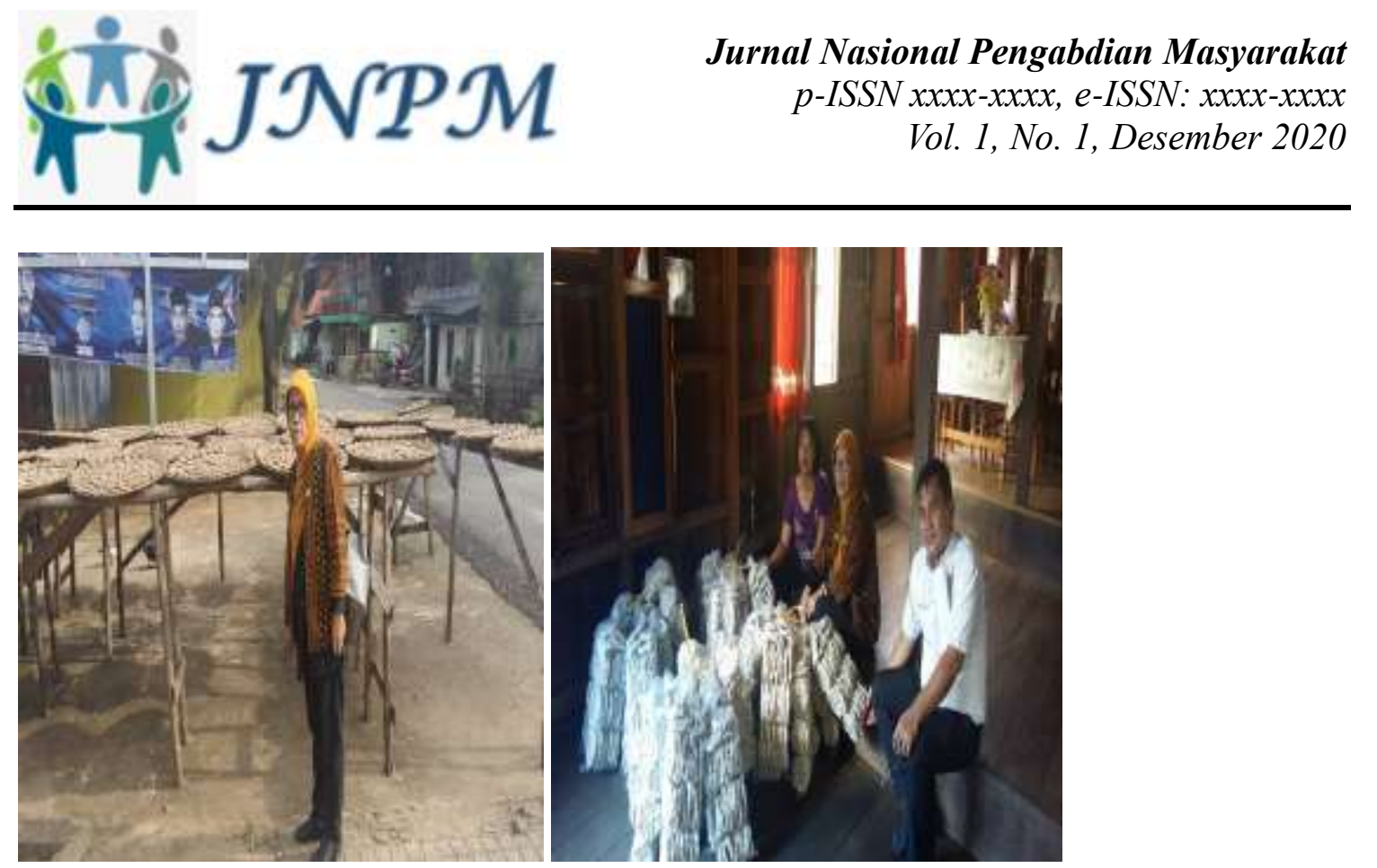

Gambar 5. Proses Penyaluran dan Penjualan Kerupuk

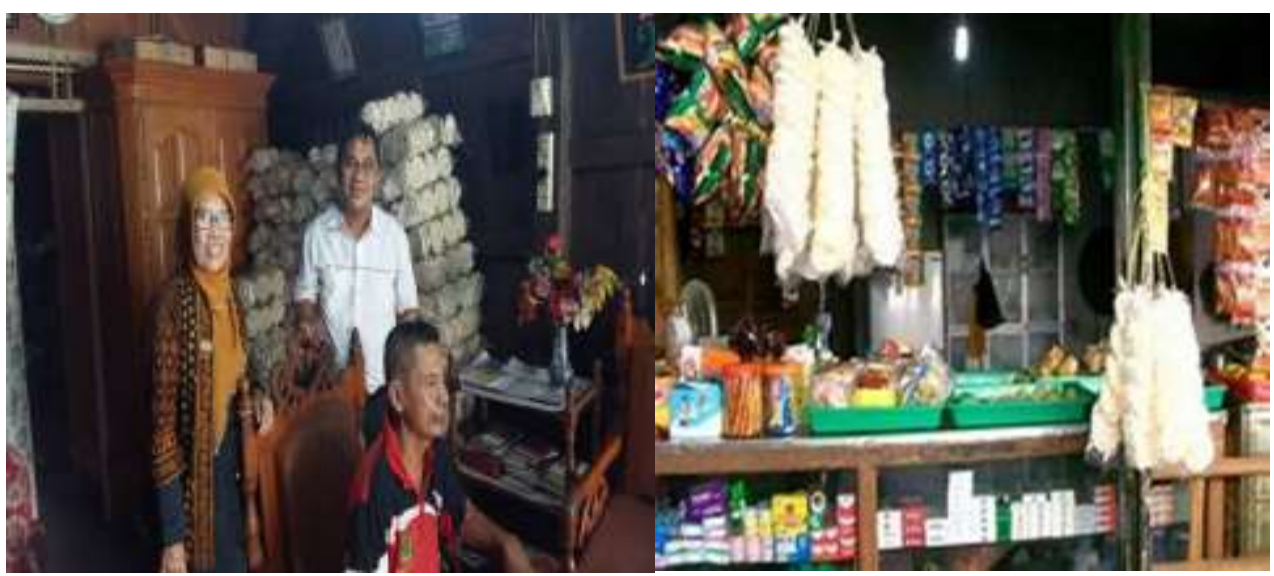

\section{Copyrights}

Copyright for this article is retained by the author(s), with first publication rights granted to the journal.

This is an open-access article distributed under the terms and conditions of the Creative Commons Attribution license (http://creativecommons.org/licenses/by/4.0/) 